\title{
Presidential New Year Greetings: What is Implied by Metaphors
}

\section{Liudmila Arcimavičienè}

\author{
cross'ref http://dx.doi.org/10.5755/j01.sal.0.24.6246
}

\begin{abstract}
In the last ten years, Critical Metaphor Analysis has been specifically applied to different varieties of political discourse. Its efficacy has also been determined by the ideological potential of metaphor, especially in the language of politics. In this article, Critical Metaphors Analysis is applied to the New Year greetings of the presidents of the Baltic States with the purpose of discerning the ideological value of the established metaphors. The qualitative data analysis has been carried out in the analytical framework of Cognitive Linguistic Approach to Metaphor Analysis, and the Pragglejaz Group's MIP has been applied for detecting metaphorical linguistic expressions and subsequently restoring conceptual metaphors. In this article, it is proposed that the evoked metaphorical frames in the New Year Greetings of the presidents of the Baltic States are not gender-specific but rather conventional metaphors evoking the political worldview of conservative morality. This might imply that, by using conventional metaphors related to the male-dominated conservative worldview, a female president of Lithuania wants to sound right thus more convincing and authoritative.
\end{abstract}

Keywords: metaphor, ideology, political discourse, the Baltic States, presidents, New Year greetings.

\section{Introduction}

Political discourse has received a lot of close attention from the proponents of cognitive linguistics in terms of critical metaphor analysis (CMA). One of the reasons why CMA has received so much acclaim in linguistic circles is its methodological potential to restore the hidden ideology of metaphors in political discourse (more on discourse analysis see Fairclough, 2001, 2003; Van Dijk, 1990). The key claim of CMA is that by identifying metaphorical expressions in text we can reflect on the effects of the underlying construal operations which are ideological in nature (see Goatly, 2007; Charteris-Black, 2011; Koller, 2004). Simultaneously, the study of metaphor is ideologically significant and contributes to the realization of discursive strategies in political discourse.

The aim of this study is two-fold. First, the metaphorical linguistic expressions are to be identified and grouped according to their representative conceptual metaphors (X IS Y). Second, it is targeted to analyse the implied ideological meaning of the discerned metaphors and gender-related differences (if any).

To achieve the above mentioned, the Cognitive Linguistic Approach to critical metaphor analysis is primarily overviewed. In the following section, the most widely spread metaphors in the language of politics and their implied meaning are presented. Then the collected and analysed research data is presented. In the following sections, it is shown what kind of perceptions about the speakers (i.e. the presidents of the Baltic States: Lithuania, Latvia and Estonia) are offered by the detected metaphors in the New Year Greetings. Finally, some concluding remarks are drawn.

\section{The Cognitive Linguistic Approach to CMA: Metaphor and Ideology}

One of the most important insights of conceptual metaphor theory is that abstract thought is only possible through the use of metaphor, which involves a mapping relation between two domains (see Lakoff, 1987; Lakoff and Johnson, 1999). The source domain corresponds to the traditional notion of the metaphor vehicle, while the target domain is equivalent to the traditional metaphor tenor (see Croft and Cruse, 2004; Grady, 1999; Gibbs, 1999; Taylor, 2002). The cross-domain correspondences are captured through the identification and analysis of metaphorical expressions reflecting the conceptual metaphor, as expressed by the form X IS Y. By analysing metaphorical expressions we do not only restore the schematic representation of metaphors but, more importantly, we also learn about people's perceptions. For that reason, Andrew Goatly (2007) refers to metaphors as cognitive filters determining particles of truth. In his view, 'different metaphors filter different particles of truth' (ibid., p. 25). This leads to another significant aspect of metaphor analysis - its ideological power.

The ideological power of metaphor has led to the synergy between Cognitive Linguistics and CDA. As rightly noted by Christopher Hart (2011, p. 271), the concerns of Cognitive Linguistics with conceptualisation are well integrated to address interpretation-stage analysis in CDA. Construal operations, including metaphor, are indexed in text and invited in text-consumers "to engender ideological cognitive representations realizing discursive strategies". Indeed, the ideological power of metaphor is determined by metaphorical models promoting social survival and well-being (see Goatly, 2007). Moreover, Goatly (2007, p. 33) assumes that there are metaphorical models as being "not conducive to the future survival" of the human race but rather threatening our social positioning and wellbeing. 
The above mentioned is invaluable for the analysis of political discourse in terms of metaphor and its ideological implications. For example, Jonathan Charteris-Black (2011, p. 49) refers to CMA as "a methodology for the analysis and interpretation of ideology". He also argues that metaphor is effective in combining moral and emotional intuition (ibid., p. 49). In his view, metaphor plays "a crucial social role in communicating ideology" (ibid., p. 51). Moreover, he refers to metaphor as

an effective means for politicians to develop persuasive arguments by applying what familiar, and already experienced, to new topics demonstrate that they are thinking rationally about political issues (ibid., p. 35).

Ultimately, this study views metaphor as a conceptual mechanism that can be realised linguistically; CMA unveils political ideology and unconscious emotions, and legitimises or delegitimises political actors.

In the following section, the most widely spread metaphors in political discourse are overviewed and their implications about political thought and action are discussed.

\section{Metaphors in Political Discourse}

The effects of metaphor in political discourse have been analysed by Lakoff and Chilton (1989), Lakoff (1987, 2004, 2006, 2011), Musolff (2004, 2006, 2008), Chilton (2004), Charteris-Black (2004, 2011), Turner (2001), etc. The most widely spread metaphors underlying the language of politics can be assigned to three different groups as follows: (1) human nature, (2) motion and (3) competitive character (see Kövecses, 2002; Lakoff and Chilton, 1989; Lakoff, 1996; Lakoff and Johnson, 1999; Chilton, 2005; Charteris-Black, 2011; Mey, 2006).

The first group refers to the metaphors of human nature which are mainly of two kinds: personification, as reflected in the STATE IS A PERSON metaphor, and the FAMILY metaphors. The STATE IS A PERSON metaphor is one of the basic foreign policy metaphors which allows us to perceive the world as a community where each state has its own 'status' and 'responsibilities' (see Lakoff and Chilton, 1989; Lakoff, 1996, 2004).

By analysing the language used by conservatives and democrats, Lakoff (1996, 2004) outlines the morality underlying their discourse. He claims that one of the reasons, why democrats lose to conservatives, is their inability to reframe their political discourse and reclaim its moral positioning (2004). The morality of the conservatives is grounded in the Strict Farther metaphor, while the democrats' morality is based on the Nurturant Parent model (1996, 2004). Lakoff (2006) also observes how the same metaphorical family models of strictness and nurturance shape the concepts of freedom as fitting into those systems of thought.

While Lakoff mainly adopts a single nation perspective for the FAMILY metaphor, Musolff (2006) analyses the use of this metaphor in a bi-lingual corpus of metaphorical texts in British and German press on the topic of the EU politics. In his study, Musolff notes that the FAMILY metaphor is closely related to the metaphors of LOVE and MARRIAGE, and he proposes that the LOVE-
MARRIAGE-FAMILY metaphorical models are common to both English and German samples (ibid., 2006).

The FAMILY metaphor has been also discussed by Charteris-Black (2011). In his study of political speeches, he argues that the FAMILY metaphor is one of the most important conceptual mechanisms in Margaret Thatcher's discourse. Moreover, he notices that as the first female Prime Minister of Britain Margaret Thatcher activates the mental FAMILY script where a woman plays a more central role (ibid., p. 191). This mental script allows Margaret Thatcher to exploit the notion of the family budget (i.e. money is safer in woman's hands) in the context of the national budget (ibid., pp. 191-192).

Another prominent metaphor in the language of politics is that of MOTION. As noted by Chilton, political discourse draws on spatial cognition, and "the perception and conception of space is of major significance" (2004, p. 203). His study also suggests that territoriality is an intrinsic part of the socio-political instinct (ibid., p. 203). Simultaneously, movement within a certain territory is then associated with a certain political act. The MOTION metaphor is closely related to the metaphor of LIFE IS A JOURNEY, which, in Johnson's view (1993), is central to human moral systems. Charteris-Black (2011) notes that this metaphor has become a familiar metaphor rooted in the language of popular imagery, which is in fact an important rhetorical component of the Conviction Rhetoric (2011, p. 236).

Finally, the COMPETITION metaphor is another conceptual frame intrinsic to the language of politics. This metaphor has different representations. It can be realized through the concepts of sports, business and war. This metaphor is based on the perception that politicians are competitors against each other or others in the fields of sport, business or war. This metaphor allows politicians to segregate people or countries into good and evil. Finally, the WAR metaphor has a moral realm (Lakoff, 2006, 2011). Politicians, using the WAR metaphor, actually claim that they do it in the name of 'good', and that any means can be justified in their fight against their perceived 'evil'.

In the following section, the contextual basis and methodological framework of the collected data will be outlined.

\section{Data and Methodology: Topic, Context and Analytical Framework}

This study raises two objectives as follows. First, the prevailing metaphors in the Presidential NY Greetings of the Baltic States are to be reconstructed; second, on the basis of the identified metaphors the ideology implications are to be inferred.

The topic issue of the NY Greetings was selected for its contextual nature of raised expectations. It is generally assumed that the New Year is a period of new hopes, new beginnings and brighter future. This message is even more intensified when the leader of a country formally acknowledges it. Thus, NY Presidential Greetings involve both a moral portrait of the speaker and his/her perceptive 
projection of the up-coming year. As the president is one of the key political and moral authorities in a country, his/her greetings have an intensified emotional significance in terms of sounding right and giving moral and political encouragement for the New Year to come.

In this study, the NY Greetings of the Presidents of the three Baltic States-Lithuania, Latvia and Estonia-have been selected for the reason of their inter-relatedness. These countries are related to each other on many terms to mention but a few: shared history, politics and economic priorities. Historically, the Baltic States have been in the Swedish (or in Lithuania's case, Polish), German, Danish, and Russian spheres of influence (see Baranauskas, 2000; Beissinger, 2009). Politically, Lithuania, Latvia and Estonia have been members of both the EU and NATO since 2004. Today, the three countries are liberal democracies and their market economies have undergone rapid expansion in 2000s (see Imf.org). Nonetheless, the global economic crisis has left its imprint on the Baltic economies, and caused rising unemployment rates and the overall fall of GDP (see Imf.org). This could imply that by having shared historic, political and economic background the presidents of the Baltic States might have similar perceptions of the future of their country. The mental representation of such perceptions is to be offered by metaphors as traced in the Presidents' NY Greetings.

For that purpose, the Presidents' NY Greetings in the time span of four years (2009-2013) were collected from the online presidential sites of each country and analysed (see Table 1). It should be noted that the collected data consists of the English versions of the New Year Greetings. This fact should not underestimate the value of the study, as it aims at restoring the speakers' perceptions of the New Year and their implied ideology. Even more, the English versions of the greetings target a global audience, especially considering the fact that the level of emigration is particularly high in the Baltic States. This might imply a higher level of expectations and more persuasive value of propositions from the selected texts.

More importantly, the gendered use of metaphor is to be tackled, that is, whether metaphoric expressions vary according to the speaker's gender. Charteris-Black's (2009) comparison of metaphors used by male and female politicians shows that conventional metaphors are more widely spread among male politicians due to their longer experience of political discourse. Hence it could be hypothesized that both male presidents of Latvia and Estonia will use a greater number of similar metaphors than the female president of Lithuania.

Pragglejaz Group's MIP (Pragglejaz Group, 2007) was employed as a research tool to identify metaphorical expressions in the selected texts. The main principle of the procedure is to identify the contextual and basic meanings of the selected expressions and decide whether these two meanings contrast but can be understood in comparison to each other (2007, p. 9).

The analysis of the identified metaphorical expressions of the selected texts has led to the following findings as reproduced in Table 1.
The findings reveal that though the female president's greetings are shorter, they are metaphorically loaded. Thus, the female president of Lithuania uses metaphorical expressions by three times more frequently than her male colleagues in Latvia and Estonia. This might support the hypothesis that gender plays a certain role in the metaphor use. However, it is important to analyse the implied meaning of the restored metaphors to decide whether the evoked metaphors ideologically vary between a woman president and male presidents.

Table 1. Research findings

\begin{tabular}{|l|c|}
\hline \multicolumn{1}{|c|}{ Presidents } & $\begin{array}{c}\text { Metaphorical Expressions in New } \\
\text { Year Greetings (2010-2013) }\end{array}$ \\
\hline $\begin{array}{l}\text { The President of } \\
\text { Lithuania } \\
\text { www.president.lt }\end{array}$ & $\begin{array}{c}\text { In total } \mathbf{4 2} \text { source domains } \\
\mathbf{1} \mathbf{~ m e} / \mathbf{1 3} \text { words }\end{array}$ \\
\hline $\begin{array}{l}\text { The President of } \\
\text { Latvia } \\
\text { www.president.lv }\end{array}$ & In total $\mathbf{4 7}$ source domains \\
\hline $\begin{array}{l}\text { The President of } \\
\text { Estonia } \\
\text { www.president.ee }\end{array}$ & $\mathbf{1} \mathbf{~ m e ~ / ~ 3 0 ~ w o r d s ~}$ \\
\hline
\end{tabular}

In the following sections, the type of metaphors each president uses will be analysed and their ideological implications will be discussed. Each of the section has two subdivisions: (1) background and (2) metaphor analysis. In the 'background' section the main facts about the president are overviewed, while in the 'metaphor analysis' section it is illustrated how metaphors disclose president's perceptions of his/her country's future and the ideological value of metaphorical frames in the context of the NY greetings.

\section{The President of Lithuania D. Grybauskaitė's NY Greetings}

\section{Background}

Dalia Grybauskaite was inaugurated as the President of Lithuania on 12 July 2009. She served a five-year term as Vice-Minister of Foreign Affairs and Minister of Finance, also European Commissioner for Financial Programming and the Budget (see Lrp.lt). Often referred to as the 'Iron Lady' or the 'Steel Magnolia', Miss Grybauskaite is Lithuania's first female head of state. One of the facts which intensifies her image of as the 'Iron Lady' is her family status and hobby in karate (i.e. she has a black belt in karate). The president does not have a family of her own, which can be viewed as her willingness to devote herself to her career and fulfill her professional ambitions. Based on these facts, it is expected that Grybauskaite's metaphors should disclose her as a strong and ambitious leader, who tries to maintain a male dominant leadership style.

\section{Metaphor Analysis}

The data on Grybauskaite totalled approximately 600 words and comprised the three NY Greetings as shown in Table 1. A close analysis revealed a total of 42 metaphorical expressions or one every 13 words - and four 
major metaphor types: STRENGTH, JOURNEY, UNITY AND PERSONIFICATION (see Table 2).

Grybauskaitè's preference for these metaphors characterizes her as a Right wing politician, whose discourse evokes a Conservative frame based on the Strict Father Family model. The Strict Father model is based on the major assumptions as follows: the world is a dangerous and competitive place to live where is a strong and strict leader protects others from dangers (see Lakoff, 1996, 2004).

Table 2. Grybauskaitè's metaphors classified by source domain

\begin{tabular}{|l|c|l|}
\hline \multicolumn{3}{|c|}{ LT President's NY Greetings } \\
\hline Source Domain & No. & Example \\
\hline (1) STRENGTH & 13 & $\begin{array}{l}\text { If we all work together for the } \\
\text { good of Lithuania, we will } \\
\text { prevail. So let us have } \\
\text { confidence in our own strength. } \\
\text { (2010) }\end{array}$ \\
\hline (2) JOURNEY & 12 & $\begin{array}{l}\text { I firmly believe that next year } \\
\text { our major difficulties will be } \\
\text { overcome. (2010) }\end{array}$ \\
\hline (3) UNITY & 6 & $\begin{array}{l}\text { Dear fellow Lithuanians, } \\
\text { wherever you are, let } \text { unity and } \\
\text { confidence stay with us } \\
\text { throughout 2012. Let } \text { us be } \\
\text { together as we create a better } \\
\text { year for ourselves, our friends } \\
\text { and families, and for Lithuania! } \\
\text { (2012) }\end{array}$ \\
\hline (4) PERSONI- & 5 & $\begin{array}{l}\text { Let us be collected and } \\
\text { deliberate as we seek daring } \\
\text { solutions and resolute economic } \\
\text { reforms to get our country back } \\
\text { on its feet. (2010) }\end{array}$ \\
\hline
\end{tabular}

Some of these features can be traced in Grybauskaitè's use of the STRENGTH metaphor, which suggests her positive evaluation of the conservative ideology. For that purpose, the president uses the pronoun 'we' alongside the STRENGTH metaphor. This pronominal use implies the unity of purpose which, in its turn, intensifies the evaluative meaning of the STRENGTH metaphor. To illustrate this, consider the statements (1) and (2) below:

(1) If we all work together for the good of Lithuania, we will prevail. So let us have confidence in our own strength (NYG, 2010).

(2) This past year was filled with serious challenges, but it also gave us wisdom and experience. We became stronger and more mature (NYG, 2011).

In (1) the STRENGTH metaphor is supported by the use of the verb 'prevail', the basic meaning of which refers to 'be widespread or become dominant'. Contextually, the use of this verb implies superiority, influence and success. This is related to one of the features of the Strict Father Morality, which characterizes a good citizen of a country as a strong and confident person, being able to dominate and win over others, hence, the mentioning of confidence in the second part of statement (1). Moreover, in (2) the noun 'challenges' evokes the competitive frame of the conservative morality, where people are divided into winners and losers. Thus, the reference to people as 'stronger' in (2) construes their status of winners rather than losers. Finally, in (1) and (2) by using the pronoun 'we' the president does not only attribute herself to this kind of people but also expects others to think and act in a similar manner, i.e. be competitive thus strong.

The use of the STRENGTH metaphor is also extended to economics. Considering the fact that the STRENGTH metaphor evokes conservative morality, it becomes clear why the president speaks about 'daring solutions' and 'resolute economic reforms' as in (3) below:

(3) Let us be collected and deliberate as we seek daring solutions and resolute economic reforms to get our country back on its feet (NYG 2010).

The metaphorical expressions in (3) demonstrate metonymic and metaphorical interplay, where a person stands for solutions and reforms (i.e. metonymy) and economy is personified (i.e. metaphor). More importantly, the use of such adjectives as 'daring' and 'resolute' suggests a conservative frame, as both attributes attached to the inanimate nouns 'solutions' and 'reforms' imply the importance of strength. The analysis of the STRENGTH metaphor has also shown that its conceptual frame underlies other metaphors. One of them is the metaphor of JOURNEY.

The JOURNEY metaphor is positively evaluated, as the New Year is seen as motion to a new path, as in (4), or a new entry, as in (6) below. In addition, the president speaks of difficulties in (5) or challenges in (6), which are presented as obstacles in her country's journey, consider the following statements below:

(4) In just a few moments, we will step into the New Year (NYG, 2012).

(5) $\quad<\ldots>$ I firmly believe that next year our major difficulties will be overcome (NY G, 2010).

(6) As we enter 2011, we are full of hope and there is good reason for it. This past year was filled with serious challenges, but it also gave us wisdom and experience (NYG, 2011).

The JOURNEY metaphor is supported by the evaluation based on the Conservative outlook in both (5) and (6). In (5) the Lithuanian president 'firmly' believes that 'difficulties will be overcome'. The adverb 'firmly' here evokes the STRENGTH metaphor by conflating its basic meaning of 'not soft, solid, hard or rigid' with a person's confidence into the general ability to resist difficulties by thus becoming stronger and more powerful. Similarly, in (6) 'challenges' are referred to as 'serious'. Thus, to face and respond to such 'serious challenges' a person needs to possess a sufficient strength of character, will and purpose. Contextually, it construes the image of a strong person framed by the conservative worldview, whose discipline and aptness to forcefully compete in the world full of dangers are implied.

Another most prevalent metaphor is that of UNITY. Similarly to the JOURNEY metaphor, the UNITY metaphor evokes the Conservative ideology and is thus closely related to the STRENGTH metaphor. The president sees togetherness of all the Lithuanians as a means of 
becoming stronger. The UNITY metaphor also refers to an emotional state of the oneness of mind and feeling; for example, the metaphorical expressions in (7), (8) and (9) activate the evaluation framework of 'togetherness' as referring to the oneness of mind, feeling and action.

(7) If we all work together for the good of Lithuania, we will prevail (NYG, 2010).

(8) Again and again, history teaches us the importance of togetherness (NYG, 2012).

(9) Next year, we will also stand together to face warm or cold winds blowing locally and globally (NYG, 2012).

In (7) the use of the conditional clause also evokes the evaluation scheme of 'togetherness', as on the condition (i.e. the use of the if-clause) that 'we work together', 'we will prevail' or become stronger in the future. Thus, unity is seen as a necessary condition for strength. In (9) the metaphorical expression of 'standing together' refers to 'solving problems together'. Even more economic policies are perceived through the source domain of 'winds blowing locally and globally'. The use of the NATURE source domain allows politicians to justify their unpopular decisions. As in the case of (9), economy is seen in terms of blowing winds, thus it is unpredictable and cannot be controlled. Nonetheless, what the president encourages Lithuanians to do is 'stand together' and 'face the winds'. This again activates the Conservative framework, in which strong people are expected to face challenges and resist them.

The last group of metaphors is represented by PERSONIFICATION. The country's personification allows the president to talk about Lithuania's as a person's efforts, as in (10), or its recovery, as in (11) below:

(10) The continued financial unrest has required special efforts from our country and families (NYG, 2012).

(11) I see signs of Lithuania's recovery and I firmly believe that next year our major difficulties will be overcome (NYG, 2010).

The metaphorical construal in (11) and (12) creates a positive evaluation framework. The president positively evaluates the country's economic and social situation. Such proposition of the country's recovery has a positive effect on the audience. While expressing her hope in a better economic future in (12), at the same time the president affirms her belief in the better year for the country. The coherence between the cognitive and the emotive dimensions of her speaking accounts for the Conservative approach to politics and morality.

We now turn to the analysis of metaphors in the NY greeting of the president of Latvia, and what his use of metaphors implies.

\section{The President of Latvia A. Bērziņš’s NY Greeting}

\section{Background}

Andris Bērziņš won the presidential election in 2011 by winning the support of 53 MPs out of 100 in a parliamentary ballot. As noted by BBC news, Mr. Bērzinšs is not only an active politician but also a businessman (2011). Aged 66, Mr. Bērziňš is a former banker turned politician in the Greens and Farmers' Union. There are some other interesting facts referred to about the president of Latvia in the media. One of them is that the president married a second time a few days before assuming his office as president. Another disturbing fact, as noted by the media, is that in $2012 \mathrm{Mr}$. Bērziñš threatened paparazzi after they came too close to make pictures of president's son with the following words: "Guys, You want me to beat you over the head? Long time you haven't been attacked" (Kasjauns.lv, 2012). As based on these facts, it is expected that his language might comprise metaphors of competitive and pragmatic character disclosed by such source domains as BUSINESS, SPORTS, WAR or STRENGTH.

\section{Metaphor Analysis}

The data on Andris Bērziňš totalled 1453 words though it comprised only one NY Greeting given by the president in 2012, as shown in Table 1. A close analysis revealed a total of 47 metaphorical expressions or one every 30 words - and four major metaphor types: PERSONIFICATION, JOURNEY, STRUCTURE and NATURE (see Table 3 below).

Table 3. Andris Bērziņš’s metaphors classified by source domain

\begin{tabular}{|c|c|c|}
\hline \multicolumn{3}{|c|}{ LV President's New Year Greeting } \\
\hline Source Domain & No & Example \\
\hline $\begin{array}{l}\text { (1) PERSONI- } \\
\text { FICATION }\end{array}$ & 17 & $\begin{array}{l}\text { The Baltic States must stand } \\
\text { together when it comes to } \\
\text { strategically important decisions. } \\
(\mathrm{NY}, 2012)\end{array}$ \\
\hline (2) JOURNEY & 8 & $\begin{array}{l}\text { A critical boundary has been } \\
\text { reached in many areas - one } \\
\text { which does not allow us to keep } \\
\text { everything the same. (NY, 2012) }\end{array}$ \\
\hline (3) STRUCTURE & 7 & $\begin{array}{l}\text { Common values, mutual respect, } \\
\text { human understanding and } \\
\text { tolerance are the foundations } \\
\text { upon which we must build } \\
\text { Latvia's future. (NY, 2012) }\end{array}$ \\
\hline (4) NATURE & 7 & $\begin{array}{l}\text { The economic upheaval which } \\
\text { brought along a reduction in } \\
\text { standards of living and a lack of } \\
\text { knowledge about the future has } \\
\text { created fertile soil for internal } \\
\text { conflicts, and this is an } \\
\text { atmosphere under which it is far } \\
\text { simpler to sow distrust and } \\
\text { confrontation. (NY, 2012) }\end{array}$ \\
\hline
\end{tabular}

The most prominent metaphor is PERSONIFICATION, due to which the president's language is highly emotive, as personified metaphors create more expressive images of abstract ideas. To illustrate, a conflict of ideas is represented more passionately as a conflict between people. As rightly noted by Charteris-Black (2011, p. 243), personification is "an important strategy of Conviction Rhetoric". In his NY Greeting the president of Latvia extensively uses the STATE IS A PERSON metaphor, especially while describing the economic crisis and diplomatic relations in the EU. First, member states are conceived as people who cannot trust each other and whose relationship is vertically structured. The 
interpersonal vertical relationship is supported by such metaphors as IMPORTANT IS BIG and AUTHORITY IS STRENGTH. The latter is implied in both (12) and (13) below.

(12) There is a lack of trust in relations among countries, there is no trust in financial stability, there is no trust in the ability of governments and international organisations to overcome this crisis properly (NYG, 2012).

(13) The strong come together, the weak face isolation, and this increases concerns about a Europe of two levels or two speeds (NYG, 2012).

The diplomatic relations of countries are conceived as the relations of people who no longer trust each other. Due to the personification in (12), the president can talk about countries' relations and, more importantly, about "a lack of trust" in these relations. In (13), he then goes on to conceptualize countries as people who are either strong or weak. This kind of division implies about the president's negative evaluation of the EU, and its distribution of power among the member states. This division of states into strong and weak also implies about their divided policies, contextually associated with "two levels or two speeds", as in (13). All this evokes the frame of competitive politics in the EU, as negatively evaluated by the Latvian president.

The frame of completive politics is also intensified by the COUNTRIES ARE PLAYERS metaphor, though it is now based on the positive evaluation. By using it, the president emphasizes his expected necessity for Latvia to be a strong player despite its small economy and population. This is invoked in the example such as (14) below.

(14) No matter how radical the scenario which occurs, Latvia must be on the strong team, because we have shown that a small economy can achieve good results <... (NYG, 2012).

The metaphorical expression of being "on the strong team" in (14) raises associations between politics and team sports.

The Conservative framework of competitive politics also receives positive evaluation in the context of the relations of the Baltic States. The president of Latvia positively uses the COUNTRY IS A PERSON metaphor in examples such as (15) and (16).

(15) Strengthening our co-operation is the key to successful development of the region. Both in terms of market sizes and in terms of foreign policy operations, the Baltic States must stand together when it comes to strategically important decisions (NYG, 2012).

(16) We (i.e. the Baltic States) must all become stronger, as opposed to separate and weaker (NYG, 2012).

The verb 'strengthen' in (16) indicates the president's positive evaluation of the relations of the Baltic States. The use of the pronoun 'our' also contributes to the idea of mutual cooperation and evokes the feeling of shared trust and understanding between the countries. The metaphorical expression of 'standing together' in (15) activates the UNITY metaphor, which implies that the president expects the Baltic States to share political and economic goals. This common strategy could make them all 'stronger' as in (16). More importantly, in (16) the president opposes strength to separation and weakness, which again illustrates the crossed conceptual boundaries of the STRENGTH and UNITY metaphors.

The second most productive metaphor is JOURNEY, whose characteristics are related to the process of motion and changes expected in the New Year. Consider (17) and (18), where the JOURNEY metaphor is evoked by the use of the nouns course and shift.

(17) Over the course of 2011, we experienced experiments with our fundamental law - the Constitution (NYG 2012).

(18) The world is changing. When recorded in history, these years will be described as ones of serious changes and shifts (NYG 2012).

The metaphorical construal in (17) and (18) is supported by the nouns both referring to motion. In (17), the NY is seen as a path during which that motion will take place, i.e. the use of the noun 'course' illustrates this perception. The use of shifts in (18)implies changes or new directions to be taken. Anything new implies unknown or unfamiliar thus unpredictable and frightening. This suggests the president's negative evaluation of the new changes in his country's life. The new changes or 'shifts' are also referred to as 'challenges', consider the following example below:

(19) The global economy is undergoing serious upheaval, and we must understand that we will not be able to avoid challenges in the coming year (NYG, 2012).

As the basic meaning of 'challenges' is related to a call to battle, contest or special effort, in the context of the NY Greeting, the president employs this word to activate the image of a difficult and problematic journey in the year to come. Moreover, in (19) the president attributes these problems to the global economic crisis 'undergoing serious upheaval', by thus showing that he and/or the Latvian government should not be held responsible for the present or future problems of Latvia's economy.

Another feature of the JOURNEY metaphor evokes the mental image of a bounded movement along a certain path. This is characteristic of the conservative politics, where new changes and ideas are seen as an act of 'transgression' from old and deeply rooted beliefs. Thus, anything new is treated with suspicion and criticism. This schema is invoked in (20) below.

(20) A critical boundary has been reached in many areas - one which does not allow us to keep everything the same (NYG, 2012).

In (20) the president negatively evaluates the forthcoming changes by attributing the adjective 'critical' to the noun 'boundary'. Moreover, in (20) the underlined phrase implies the president's conservative attitude to the new changes, which is about 'keeping everything the same'. The use of the passive voice in the first part of the statement also indicates the speaker's positioning. By using the passive, the Latvian president distances himself from the present and future problems in the country by attributing their cause to external factors. Similarly, this schema is evoked in the example (21) below. 
(21) Yes, governments are local, but economic processes are becoming more and more global, and they often leave behind very damaging consequences, indeed (NYG, 2012).

In (21) the TERRITORY metaphor is supported by the use of the juxtaposed adjectives 'local' vs. 'global' and the verbal phrase 'leave behind'. In this context, the president of Latvia contrasts local governments with global economic processes, where the latter are perceived as those external factors creating problems. Thus, local governments cannot be held responsible for the economic problems in the country. Even more, the personification of the economy and its construal of as the main antagonist shows the president's intention to both evade responsibility and shift it to a non-existent entity of 'global economy'.

The third metaphor is that of STRUCTURE, whereby two experiences are correlated: the specific experience of constructing a structure is mapped on the abstract experience of governing a state, as reflected in the STATE IS A STRUCTURE metaphor. The president's linguistic choices show his positive evaluation of this metaphor in highlighting the aspect of 'foundation', e.g.:

(22) The foundation of foundations and the key for our future must, therefore, be an orderly state and good relations among our people (NYG, 2012).

(23) Common values, mutual respect, human understanding and tolerance are the foundations upon which we must build Latvia's future (NYG, 2012).

In (22) the president assigns the foundation of the state to 'an orderly' state and good relations. The former is another metaphoric expression underlying the STRUCTURE metaphor. The use of the adjective 'orderly' also evokes the STRUCTURE metaphor by raising an implication that the state should consist of regularly sequenced blocks, as any firm construction does. The STRUCTURE metaphor can also be evoked by the concept of stability, as in (24) and (25):

(24) Politicians and the government must stabilise the country's finances, establish an educational system which is in line with modern requirements, promote business and self-initiative and, particularly, keep people from emigrating from Latvia, because without people, we will have no Latvia (NYG 2012).

(25) I stand prepared to work on behalf of these goals and to do everything in my power to ensure that life in Latvia becomes better, safer and more stable (NYG 2012).

In this context, stability is associated with a positional firmness of the structure; hence, it is seen as an essential feature of a 'strong' state. Besides strength, stability also implies economic well-being, in (24) and safety in (25). In (24), the STRUCTURE metaphor is also supported by the metaphorical expression "keep people from emigrating from Latvia", with Latvia seen as a container.

The last metaphor to be discussed in this section is that of NATURE. The source domain of NATURE is evoked in both political and economic contexts. By using this metaphor the president of Latvia indirectly tries to persuade that his country's problems have naturally evolved and been determined by natural causes. Economic problems are thus seen as natural phenomena that cannot be controlled by people but negatively affects their life. To illustrate this, consider the example in (26):

(26) My fellow people of Latvia, the economic upheaval which brought along a reduction in standards of living and a lack of knowledge about the future has created fertile soil for internal conflicts, and this is an atmosphere under which it is far simpler to sow distrust and confrontation (NYG, 2012).

In (26) the metaphorical expression "the economic upheaval" is used with active verbs such as 'brought along' and 'created'. This is how normally various natural phenomena are described, as in "Strongwinds have pushed sheets of ice on to the shores of Lake Mille Lacs..." (BBC News, 12 May 2013). In this view, the metaphorical pattern of THE ECONOMY IS A NATURAL PHENOMENON allows the president to evade responsibility for serious economic problems and delegate it to nature rather than the Latvian government. Finally, by using the NATURE metaphor the president legitimises himself and delegitimizes globalisation by presenting it as a threat to Latvia. For example, consider the statement in (27) below:

(27) Globalisation in the world will gradually erase national boundaries, the role of individual countries will diminish, and only the Latvian lifestyle and environment will encourage us to preserve our country (NYG, 2012).

Here it is construed that globalisation is a natural phenomenon threatening Latvia and its lifestyle, and the use of the active verb points to that (i.e. "globalisation will erase"). The use of the noun 'national boundaries' also contributes to the metaphorical construal of 'natural disaster': where globalisation is seen as a threat to negatively affect the territorial positioning of the nation (i.e. Latvia). Similarly, the use of the verb 'preserve' implies the necessity to keep Latvia safe from external forces and influences. The positive meaning of 'preserve' explains the president's pronominal use of 'us' and 'our', as initiated by the president's implications about his personal involvement in 'preserving' his country.

In the following section, the metaphor use in the NY Greetings of the President of Estonia T. H. Ilves will be discussed.

\section{The President of Estonia T. H. Ilves's NY Greetings}

\section{Background}

Mr. Ilves is the fourth president of Estonia, in office since 2006. In the 1990s he was the leader of the Social Democratic Party, he also worked as a diplomat and a journalist. He was elected and served two years as a Member of the European parliament. In September 2006 he was elected as president of Estonia by an electoral college, and his term as president began in October 2006.

Besides, there are some interesting facts characterising Mr. Ilves as a creative and overtly emotional person. One of them is that in public he almost exclusively wears blow ties. Another is related to his response to Paul Krugman's negative evaluation of Estonia's economic recovery on the social network Twitter. The president of Estonia reacted in a series of outraged twits, blaming Krugman for his 
inadequate tone and economic inaccuracy (Jeltsen, 2012). Martel explains that as his need "to clarify that he was not conservative or leftist" (2012). Considering these facts, it is expected that the president of Estonia will be more expressive in his NY Greetings by using less traditional metaphors delineating more liberal and a less conservative worldview.

\section{Metaphor Analysis}

The data on Mr. Ilves totalled 1863 words though it comprised two NY Greetings given by the president in 2011 and 2013, as shown in Table 4. A close analysis revealed a total of 55 metaphorical expressions or one every 33 words - and four major metaphor types: JOURNEY, PERSONIFICATION, COMMODITY and STRENGTH/STRUCTURE(see Table 4 below). The last group consists of two metaphors which were used with the same frequency of occurrence. It should be noted that the president of Estonia, similarly to the president of Latvia, uses three times less metaphorical expressions than the president of Lithuania. It can be assumed that male presidents tend to use less metaphors than a female president. However, the greater importance is given on the nature of metaphors and their ideological implications.

Table 4. T.H. Ilves's metaphors classified by source domain

\begin{tabular}{|l|c|l|}
\hline \multicolumn{3}{|c|}{ EE President's New Year Greetings } \\
\hline Source Domain & No. & Example \\
\hline (1) JOURNEY & 16 & $\begin{array}{l}\text { We took another step } \\
\text { towards the normality in } \\
\text { which we no longer suffer } \\
\text { with gritted teeth just } \\
\text { because we have to, just } \\
\text { because we have become } \\
\text { used to doing so. (2013) }\end{array}$ \\
\hline (2) PERSONI- & 13 & $\begin{array}{l}\text { The year, which we are } \\
\text { about } \text { to welcome in, will not } \\
\text { necessarily bring relief to } \\
\text { everyone in this regard. } \\
\text { (2011) }\end{array}$ \\
\hline (3) COMMODITY & 7 & $\begin{array}{l}\text { Democracy is not for sale. } \\
\text { Respect cannot be bought. } \\
\text { (2011) }\end{array}$ \\
\hline (4) STRENGTH / & $6 / 6$ & $\begin{array}{l}\text { Twenty years have already } \\
\text { passed since Estonia restored } \\
\text { its independence.(2011) }\end{array}$ \\
\cline { 2 - 3 } & $\begin{array}{l}\text { But, above all, we must have } \\
\text { the will to emerge from this } \\
\text { difficult situation. (2011) }\end{array}$ \\
\hline
\end{tabular}

As given in Table 4 above, the most prominent metaphors are those of JOURNEY and PERSONIFICATION. The same source domains were found in the greetings of both Latvian and Lithuanian presidents. The COMMODITY metaphor is a single source domain that was used exclusively by Mr. Ilves.

Mr. Ilves's JOURNEY metaphor serves as an ideological platform to linearly and progressively perceive time and raise positive feelings by referring to a more promising and brighter future. In this context, the journey is perceived as a purposeful motion bounded in the patterns of time with its beginnings and final stages. To illustrate this, consider the statements (28) and (29):

(28) Today, we look back over the past year as it comes to an end and all weigh up its positives and negatives in our own minds; and we will all come to our own conclusions. In the end, I sincerely hope that our shared joys and successes will outweigh any adversities (NYG, 2011).

(29) We can sense that the downturn in our economy and our prosperity is about to end and our recuperation is about to begin (NYG, 2011).

In both (28) and (29) the president upholds a linear measurement of time, where he views people as travellers on their journey to a more prospective future. In this view, the past year is given as something behind the speaker, as in (29) "we look back over the past year", or coming to an end, as in both (28) and (29); the new year, by contrast, signifies a new beginning. In (29) the JOURNEY metaphor is also supported by the metaphorical phrase "the downturn in our economy", where 'a turn downward' refers to economic decline. More importantly, he does that by providing positive moral evaluation to the country's JOURNEY and by thus implying his moral credibility during that journey.

In (30) this is achieved by the expression of 'the right steps', wherein by using the adjective 'right', a positive evaluation is given to the decisions and acts undertaken by the Estonian government during the time of economic crisis. Even more, the president's pronominal use of the inclusive 'we' allows him to share the responsibility for the undertaken decisions with his listeners. Similarly in (31) and (32), the use of the inclusive 'we' alongside the JOURNEY metaphor gives more emotional intensity to its overall ideological value, e.g.:

(30) The crisis did not evolve into a catastrophe because when things became difficult - and even before the lean times began - we mostly took the right steps (NYG, 2011).

(31) But, above all, we must have the will to emerge from this difficult situation. To learn again and to lead. To stand up and start again (NYG, 2011).

(32) $\underline{\mathrm{We}}$ are aware of our strengths and realise our weaknesses. All of this knowledge must now be used to establish new goals (NYG, 2011).

Ideologically, Ilves's JOURNEY metaphor evokes the conservative morality. In (31), it is evoked by the expressions of "have the will", "to lead", "to stand up and start again". Such perception underlies the conservative outlook on human nature and politics in general (see Johnson, 1993 Lakoff, 1996; Lakoff and Johnson, 1999). In its view, people are expected to have strong will, realise their strengths and weaknesses (as in (32)) and show resistance to any difficulties they might face. Thus, by using the JOURNEY metaphor the president of Estonia raises such expectations and gives positive evaluation to conservative values.

Another feature noticeable about Mr. Ilves's JOURNEY metaphor is its combination of ideological potential and emotional value. By using this metaphor in combination with repetition and gradation, as in (33) below, the president does not only emotionally intensify his NY greeting but also ideologically implies the importance of 
unity and progressive movement. The positive evaluation given to the expression of 'on our way towards the future' shows the president's intention to arouse patriotic feelings and favourable attitude towards the government. Consider the statements (33) and (34) below.

(33) Today, we can say with full confidence that we are on our way. We are on our way towards the future; Estonia is on its way towards the future!

(34) Let us support each other, as we walk this way together. Let us have love, understanding, and caring for our fellow travellers on this journey.

In (34) the emphatic tone is set by such abstract nouns as 'love', 'understanding' and 'caring'. More importantly, the president expresses his emotional bond with the listeners by blending UNION with the JOURNEY metaphor. The UNION metaphor in combination with the JOURNEY metaphor rather evokes a more integrated approach to politics, as based on empathy, cooperation and collective decision-making.

The positive value of this metaphor is also sustained by the pronominal use. The importance of the pronominal use can be explained by its effect on the identity alignments made by the speakers in political discourse (see Wilson, 1990). To illustrate this, consider the contrast between (35) and (36):

(35) This is what we saw in 2012. We took another step towards the normality in which we no longer suffer with gritted teeth just because we have to, just because we have become used to doing so (NYG, 2013).

(36) An election victory does not mean that one can steamroll over all opposition by referring to one's mandate (NYG, 2013).

In (35) the inclusive 'we' serves several purposes: first, it creates a positive emotional background, where the country' life is metaphorically viewed as a unifying journey for citizens-as-travellers; second, it has an implied meaning of political manipulation, whereby the responsibility for certain political decisions is shared with the public. By contrast, in (36) the JOURNEY metaphor has a different evaluation framework. Both the use of the metaphorical expression "steamroll over the opposition" and the use of the pronoun 'one' show the president's negative evaluation of the relations between the government and the opposition. Here the use of 'steamroll over' construes an image of a forceful and coercive politics. The neutral 'one' contributes to the negative evaluation by both excluding the president from this inappropriate behaviour and directing attention to the wrong-doings of the newly elected government against the opposition.

The second metaphorical construal is that of PERSONIFICATION. Similarly to his colleagues, the president of Estonia frequently personifies and attributes human qualities to his country. By using the COUNTRY IS A PERSON metaphor the president conceptualizes Estonia as a person and attributes to it such human characteristics as strength, health, and maturity. This is how a story of a successful person is created. For example, consider how the COUNTRY IS A PERSON metaphor realised in the statements (37), (38) and (39) below.
(37) I see it as a year during which Estonia visibly matured (NYG, 2013).

(38) In February, our independent country will turn 95 years old (NYG, 2013).

(39) It always puzzles me when I hear someone moan that Estonia no longer has a common goal for which to strive (NYG, 2011).

As illustrated above, Estonia is conceptualised as a person who is mature as in (37), independent as in (38) and purposeful as in (39). The use of these concepts activates a frame of the conservative ideology, where a person is expected to always develop (i.e. maturity), be autonomous (i.e. independence) and persevere one's ambitions (i.e. purposeful). This kind of metaphor especially sounds right during the time of economic downturn.

The third metaphor is that of COMMODITY as applied to political (e.g. democracy, economy, elections) and moral contexts (e.g. respect, human relationship). The president evokes one of the most widely spread metaphors in the language of economics - STATE IS A COMMODITY. In (40), Estonia is construed as a commodified object that can be 'managed' and its progress 'measured'. Consider how the COMMODITY metaphor refers to politics in (40) and (41) below.

(40) Secondly, tough times allow us to calmly reflect on how we manage our country and measure our progress $(\mathrm{NYG}$, 2011).

(41) Elections are a contract between the voters and those elected, not merely a one-off transaction (NYG, 2013).

In the context of (40), the STATE IS A COMMODITY metaphor is closely related to the QUALITY IS QUANTITY metaphor. Their interplay suggests that Mr. Ilves associates politics with progressive management leading to quantifiable results. This construal hints at the capitalistic ideology where happiness and contentment are measured by the number of the possessed objects. In the context of the NY Greetings, the COMMODITY metaphor may have a positive emotional effect on listeners, as people tend to believe that economic progress resulting in the increasing consumption can guarantee emotional fulfillment or happiness. In this view, the country is seen as a manageable commodity. The president also uses an inclusive pronoun 'we' by thus diverting attention from the government to the people and sharing economic responsibility with the people.

The last group of metaphors consists of the STRENGTH and STRUCTURE source domains. These metaphors also evoke the characteristic features of the conservative ideology. Life is presented as a challenging journey that can be managed by strong and willful people, as in (42). The ability to manage the state is seen as an ability to control it, as in (43), e.g.:

(42) We must have both the will and ability to ask for help and to give it. But, above all, we must have the will to emerge from this difficult situation (NYG, 2011).

(43) This must be ruled out completely, if we want to remain in control of our own country (NYG, 2011).

(44) The central topic of the census year has been migration and population decline. Some declare this to be the beginning of the downfall for both the state and the people (NYG, 2013). 
The representations in (42) and (43) both activate the schema of conservative morality, as based on the perception that only a moral person with a strong will can solve problems. By contrast, in (43) and (44) the conservative ideology is evoked by the use of the VERTICAL STRUCTURE (i.e. MORE IS UP) metaphor, whereby the state is seen as a vertical structure, and its 'downfall' implies economic, moral and social devolution. The use of the STRENGTH and STRUCTURE metaphors implies about the president's ideological preference for the vertical distribution of power in politics.

\section{Concluding remarks}

I hope that it has been demonstrated that, and how, the analysis of metaphors in the NY Greetings of the Presidents of the Baltic States reveals the presidents' evaluation of politics in terms of metaphors and their ideological power. Despite the fact that the findings suggest certain differences in the frequency of the use of metaphorical expressions, the restored metaphors are not gender-specific but rather conventional mappings underlying the political discourse of male leadership style.

By applying the Pragglejaz Group's MIP in the framework of cognitive linguistics, the identified metaphors and their implied ideology have shown that the presidents of the Baltic States share the same political worldview of conservative morality.

The most frequently used and shared source domains by the presidents are STRENGTH, JOURNEY and PERSONIFICATION. By evoking the STRENGTH metaphor, the presidents expect of their country and its people to be strong, bold and wilful in character, actions and choices they make. Via the JOURNEY metaphor, the presidents raise expectations for the country and its people's willingness to overcome obstacles and face challenges with appropriate determination and courage. Finally, the shared PERSONIFICATION metaphor has a two-fold function. First, it emotionally intensifies presidents' messages by creating a more expressive image of such abstract entities as country, economy or democracy. Second, the PERSONIFIED metaphor helps to restore the following set of human attributes positively evaluated by the presidents: strength, maturity, autonomy, responsibility, ambitions and some others.

In addition to the shared metaphors, some specific metaphors have been identified. The president of Lithuania D. Grybauskaite emphatically uses the UNITY source domain, by which she emphasises the importance of 'togetherness' for a nation's future. This can be related to the perception of a woman's role in a family (i.e. the STATE IS A FAMILY metaphor). It is generally assumed that a woman regulates and sustains relations in a family thus unifies it. This family unity expectation was applied to the state unity expectations. By contrast, the president of Latvia uses the NATURE source domain with its ideological power to justify political and economic blunders by assigning them to natural cause-and-effect phenomena. The president of Estonia uses a specific metaphor of COMMODITY as related to the 'cost-and- benefit' ideology applied both to his country and its people.

Finally, the analysis has shown that the three presidents of the Baltic States use conventional metaphors. This might imply that, by using conventional metaphors related to the male-dominated conservative worldview, a female president of Lithuania wants to sound convincing and authoritative.

\section{References}

1. Baranauskas, T., 2000. Lietuvos valstybės ištakos. Vilnius.

2. BBC News, 2011. Andris Berzins Elected New President in Latvia. Available at: http://www.bbc.com/news/world-europe-13628945 [accessed November 2012].

3. Beissinger, M., 2009. The Intersection of Ethnic Nationalism and People Power Tactics in the Baltic States. In: A. Roberts, T. A. Garton, eds. Civil Resistance and Power Politics: The Experience of Nonviolent Action from Gandhi to the Present. Oxford: Oxford University Press, pp. 231-246.

4. Biography of the President of the Republic of Lithuania Dalia Grybauskaitè. Available at: http://www.lrp.lt/en/institution/president_ dalia_grybauskaite_399/biography.html [accessed April 2013].

5. Charteris-Black, J., 2004. Corpus Approaches to Critical Metaphor Analysis. Basingstoke: Palgrave-Macmillan. http://dx.doi.org/10.1057/9780230000612

6. Charteris-Black, J., 2009. Metaphor and Political Communication. In: A. Mussolf, J. Zinken, eds. Metaphor and Discourse. Basingstoke and New York: Palgrave Macmillan, pp. 97-115.

7. Charteris-Black, J., 2011. Politicians and Rhetoric: The Persuasive Power of Metaphor. London: Palgrave Macmillan. http://dx.doi.org/10.1057/9780230319899

8. Chilton, P., 2004. Analysing Political Discourse: Theory and Practice. London and New York: Routledge (Taylor and Francis Group).

9. Chilton, P., 2005. Manipulation, Memes and Metaphors: The Case of Mein Kampf. In: L. de Saussure, P. Schulz, eds. Manipulation and Ideologies in the Twentieth Century. John Benjamins, pp. 5-45. http://dx.doi.org/10.1075/dapsac.17.03 chi

10. Croft, W., Cruse, A., 2004. Cognitive Linguistics. Cambridge: Cambridge University Press. http://dx.doi.org/10.1017/CBO9780511803864

11. Fairclough, N., 2001. Language and Power. London: Pearson Education Limited.

12. Fairclough, N., 2003. Analysing Discourse. London: Routledge.

13. Gibbs, R., 1999. Researching Metaphor. In: L. Cameron, G. Low, eds. Researching and Applying Metaphor. Cambridge: Cambridge University Press, pp. 29-47.

14. Goatly, A., 2007. Washing the Brain. Metaphor and Hidden Ideology. Amsterdam: John Benjamin Publishing Company. http://dx.doi.org/10.1075/dapsac.23

15. Grady, J., 1999. A Typology of Motivation for Conceptual Metaphor: Correlation vs. Resemblance. In: R.Gibbs, G. Steen, eds. Metaphor in Cognitive Linguistics. Amsterdam: John Benjamins, pp. 79-100. http://dx.doi.org/10.1075/cilt.175.06gra

16. Hart, Ch., 2011. Force-Interactive Patterns in Immigration Discourse: a Cognitive Linguistic Approach to CDA. In: Discourse and Society. Available at: http://das.sagepub.com/content/22/3/269S [accessed December 2012].

17. Imf.org. Report for Selected Countries and Subjects. Available at: http://www.imf.org/external/pubs/ft/weo/2009/02/weodata/weorept. aspx? sy $=2007 \&$ ey $=2014 \&$ scsm $=1 \&$ ssd $=1 \&$ sort $=$ country\&ds $=. \& b r=1$ $\&$ pr $1 . \mathrm{x}=100 \& \mathrm{pr} 1 . \mathrm{y}=6 \& \mathrm{c}=946 \% 2 \mathrm{C} 939 \% 2 \mathrm{C} 941 \& \mathrm{~s}=\mathrm{NGDPD} \% 2 \mathrm{CPPP}$ GDP\%2CLP\&grp=0\&a= [accessed June 2011].

18. Jeltsen, M., 2012. President of Estonia Slams Paul Krugman: 'Smug, Overbearing \& Patronizing'. Huffington Post. Available at: http:/www.huffingtonpost.com/2012/06/06/estonia-krugman-toomashendrik-ilves_n_1575937.html [accessed December 2012].

19. Johnson, M., 1993. Moral Imagination: Implications of Cognitive Science for Ethics. Chicago and London: Chicago University Press. 
20. Kasjauns.lv, 2012. Available at: http://www.kasjauns.lv/lv/zinas/92966/ prezidents-berzins-agresivs-cali-pa-galvu-vajag-ja-video [accessed April 2013].

21. Koller, V., 2004. Metaphor and Gender in Business Media Discourse: a Critical Cognitive Study. Basingstoke: Palgrave Macmillan. http://dx.doi.org/10.1057/9780230511286

22. Kövecses, Z., 2002. Metaphor: a Practical Introduction. Oxford University Press, Oxford.

23. Lakoff, G., 1987. Women, Fire, and Dangerous Things: What Categories Reveal About the Mind. Chicago: University of Chicago Press. http://dx.doi.org/10.7208/chicago/9780226471013.001.0001

24. Lakoff, G., 1996. Moral Politics: How Liberals and Conservatives Think. Chicago: Chicago University Press.

25. Lakoff, G., 2004. Don't Think of an Elephant! Know Your Values and Frame the Debate: The Essential Guide for Progressives. The USA: Chelsea Green Publishing Company.

26. Lakoff, G., 2006. Five Years After 9/11: Drop the War Metaphor. Available at: http://www. huffingtonpost.com/george-lakoff/five-yearsafter-911-drop_b_29181.html [accessed November 2009].

27. Lakoff, G., 2011. The New Obama Narrative. Available at: http://www.huffingtonpost.com/george-lakoff/the-new-obamanarrative_b_815326.html [accessed July 2012].

28. Lakoff, G., Chilton, P., 1989. Foreign Policy by Metaphor. The CRL Newsletter, 3 (5). University of California, pp. 1-19.

29. Lakoff, G., Johnson, M., 1999. Philosophy in the Flesh: The Embodied Mind and its Challenge to Western Thought. New York: Basic Books.

30. Martel, F., 2012. Estonian President Toomas Ilves Tears Into Paul Krugman On Twitter. Mediaite. Available at: http://www.mediaite. com/online/estonian-president-toomas-ilves-tears-into-paul-krugmanon-twitter/ [accessed November 2012].

31. Mey, J., 2006. Metaphors and Activity. In: Essays on Metaphor in Language and Thought, special edition of D.E.L.T.A. 22, pp. 45-66.
32. Mussolf, A., 2006. Metaphor Scenarios in Public Discourse. Metaphor and Symbol, 21 (1), pp. 23-38. http://dx.doi.org/10.1207/s15327868ms2101_2

33. Mussolf, A., 2008. What Can Critical Metaphor Analysis Add to the Understanding of Racist Ideology? Recent Studies of Hitler's Antisemitic Metaphors. Critical Approaches to Discourse Analysis across Disciplines, 2 (2), pp. 1-10. Available at: http://cadaad.org/ejournalS. [accessed November 2009].

34. Mussolff, A., 2004. Metaphor and Political Discourse. Analogical Reasoning in Debates about Europe. England: Palgrave-Macmillan. http://dx.doi.org/10.1057/9780230504516

35. Pragglejaz Group, 2007. MIP: A Method for Identifying Metaphorically Used Words in Discourse. Metaphor and Symbol, 22 (1), pp. 1-39. http://dx.doi.org/10.1080/10926480709336752

36. Taylor, J. R., 2002. Cognitive Grammar. Oxford: Oxford University Press.

37. Turner, M., 2001. Cognitive Dimensions of Social Science. Oxford: Oxford University Press.

38. Van Dijk, T., 1990. Social Cognition, Social Power and Social Discourse, pp. 130-157. Available at: http://www.discourses.org/ OldArticles/Social\%20Cognition, $\% 20$ Social\%20Power\%20and\%20So cial\%20Discourse.pdfS [accessed July 2009].

39. Wilson, J., 1990. Politically Speaking: The Pragmatic Analysis of Political Language. Oxford: Blackwell.

\section{Data Sources}

1. NYG of the President of Lithuania. Available at: http://www.president.lt/en/activities/speeches.html

2. NYG of the President of Latvia. Available at: http://www.president.lv/pk/content/?cat_id=603.

3. NYG of the President of Estonia. Available at: http://www.president.ee/en/media/statements/index.html.

Liudmila Arcimavičienè

\section{Metaforos ideologinis vertinimas prezidentu naujametiniuose sveikinimuose}

Santrauka

Šio straipsnio tikslas - nustatyti, koki ideologini vertinima perteikia metaforos Baltijos šaliu prezidentu naujametiniuose sveikinimuose. Tyrimui buvo pasirinkti dabartinių prezidentų (D. Grybauskaitès, T. H. Ilveso, A. Berzinio) 2009-2013 metų naujametiniai sveikinimai. Remiantis teoriniais kognityvinès lingvistikos principais bei taikant kokybinį analizès metodą (angl. the Pragglejaz Group's MIP) yra ne tik nustatomi metaforiniai kalbiniai pasakymai, rekonstruojamos metaforos, bet ir vertinama jų ideologinė reikšmė. Pagrindinis šio metodo principas yra siejamas su kontekstinės ir tiesioginės pasakymo reikšmės analize. Jeigu kontekstinė ir pagrindinė žodžio reikšmès skiriasi, bet yra įmanomas jų palyginimas, toks žodžių junginys pažymimas kaip metaforinis. Šio tyrimo metaforinių pasakymų analizė leidžia teigti, kad, nepaisant tam tikrų lyčių skirtumų (t. y. kiekybiniai metaforinių pasakymu rodikliai), Baltijos šalių prezidentai naudoja tradicines metaforas, būdingas konservatizmo ideologijai. Dèl to Lietuvos prezidentès D. Grybauskaitès politinis diskursas pasižymi vyrišku vadovavimo stiliumi, kuris pozicionuoja ją kaip autoritetingą šalies vadovę ir kurios kalbèjimas skamba įtaigiai.

\section{About the author}

Liudmila Arcimavičiene, Dr., Vilnius University, Institute of Foreign Languages, Lithuania.

Academic interests: cognitive linguistics, conceptual metaphor, CMA, media political discourse, news media, political philosophy.

Address: Vilnius University, Institute of Foreign Languages, Universiteto str. 5, LT-01513 Vilnius, Lithuania.

E-mail: liudmila.arcimaviciene@gmail.com 